\title{
Improving The Students' Ability In Writing Recount Text Through Guided Picture of Class X DKV 2 Semester 1 at SMKN 1 Banyuwangi In The 2017/2018 Academic Year
}

\author{
Karyati
}

English Education Departement, PGRI University of Banyuwangi

$\begin{array}{ll}\text { Received } & \text { : Monday, April 23, } 2018 \\ \text { Revised } & \text { : Thursday, April 26, } 2018 \\ \text { Accepted } & \text { : Monday, April 30, } 2018\end{array}$

\section{Abstract}

This classroom action research discussed certai ways to solve students difficulties in composing recount, and the researcher would like to develop the technique of learning composing recount through guided picture, and the problem of this research is: How can the students' ability in writing recount text through guided picture of X DKV 2 Semester 1 at SMKN 1 Banyuwangi in the 2017/2018 Academic Year be improved?. This classroom action research applied the strategy in order to improve the students' ability in writing composition of recount text, and the strategy which is used in teaching writing composition is the use of guided picture as the media..

The use of guided pictures as media in teaching writing composition of recount can improve the students' ability of class $X$ DKV 2 SMKN 1 Banyuwangi. It can be seen in the result of cycle I and cycle II. From preliminary test, the students writing composition of recount score ranged from 55 to 68, there were 24 students. It gradually improved to $37.1 \%$, it means that the score range in cycle 1 was from 55 to 68 there were 11 students. In cycle 2, there were 9 students in the score range from 55 to 68 . It means that there was $5.7 \%$ achievement. It can be concluded that the test result from pre-action, cycle 1, to cycle 2 have had improved significantly based on the criteria of success which has been stated in previous chapter that is $75 \%$.

On the other hand, it can be concluded that the students' motivation and interest in learning writing composition of recount are also improved

Keywords:Writing composition of recount, guided pictures

\section{A. Introduction}

English is considered as an international language that becomes the most important language in the world. As a meant of communication, English is widely spoken all over the world. Realizing the important role of the English language, the government makes it on of the compulsory subjects at schools. English is learned formally as a foreign language at schools beginning from Elementary school up to university level.

English teaching learning consist of four language skills, those are, reading, writing, listening, and speaking. In fact, writing activity in 
Vocational High School as one on four language skills gets less attention, because the aspect of writing ability is not included in passing grade criteria of National Final Examination. But if 'writing composition' is not taught to the students, they will not be able to write a composition which is a part of compotence standard in 'Curriculum 2013' (kurikulum tahun 2013) because in teaching English there are four language skills which should be mastered by the students based on the standard level of education, whether they are Junior High School, Senior High School or Vocational High School.

There were nineteen classes for tenth grade in SMKN 1 Banyuwangi, and all these classes have been in the same criteria of cognitive, psychomotor, and affective aspect, but when the research taught in the X DKV 2, she found that the students of class X DKV 2 had the lowest score in writing composition, especially in composing a recount.

Moreover, the writing activity will be useful for the students when they are in high level of education or in their life society. As it has been stated in The English Curiculum (2004: 10), "It is the goal of teaching English which force students to be able to listen, speak, and read". It is obvious that writing as one of the four language skills must be taught in Junior High School, even though it is obtained from the observation conducted the pre action test to know the students' ability in writing composition of recount, and the scores show that students' of class $X$ DKV 2 got the lower score.

Actually, writing activity is not as the difficult subject to be learned as the students thought. If the students are interested and try to practice regularly in writing composition, it will be easier for them.

In order to know the casual factor of the students ' ability in writing composition of recount, the research observesed the teaching writing composition. From the observation it is found that the main factor is from the students themselves and the other one is from the teacher.

The casual factor from the students is that the students can not imagine, express their ideas, and then put it into the composition form. The students are not able to construct some word into sentences and composing them into a good composition, in short it can be said that they are difficult to master everything about writing composition of recount, or example, how they begin to write the composition of recount, or how they arrange their word into a good paragraph, or how they catch their ideas. All of them are not interesting for the students, and usually the students got bored in writing composition. The other factor is from teacher, as long as the time, the teacher only uses the classical ways to explain the writing compostion of recount without understanding from the student who got some difficult about it. The teacher is also not creative in using media which can help the students to make a good composition.

Moreover, the test result in teaching learning writing composition of recount when the researcher did the pre-action activity showed that 
the students of SMKN 1 Banyuwangi in Class X DKV 2 had low mastery in writing recount.

Related to the problem which are faced by students of class $X$ DKV 2 at SMKN 1 Banyuwangi who got difficult how to begin or start writing a composition of recount, the English teacher is expected to be able to help the students by creating an attractive situation in the teaching learning process. In this case the English tacher or the research can motivate the students by creating an attractive an interesting way in order to help the students in practicing to make a composition of 'recount'. So, it is important to choose an applicable technique for composing 'recount' that is by using an iteresting media in the teaching learning process. The media which is used to practice 'composing recount' is a pictures, especially guided pictures, or it cant be said that composing recount through guided pictures as the media will develop the students' writing skill.

Dealing with the explanations above, the research is interested in conducting the classroom action research entitled "Improving the Students' Ability In Writing Recount Text through Guided Picture of Class $X$ DKV 2 Semester 1 at SMKN 1 Banyuwangi in the 2017/2018 Academic Year".

\section{B. RESEARCH METHOD}

The design of the research which was chosen by researcher was Classroom Action Research. This research was focused in teaching learning process by finishing understanding of writing ability in recount and defining the research problem, carrying out the action of research and doing reflection. This research is intended to improve the ability of students of class XI DKV 1 at SMKN 1 Banyuwangi in writing recount text through guided pictures. The action is conducted by the English teacher in which cycle convered four stage activities, namely, planning of the action, implementation of the action, observation evaluation, and reflection.

The Variable of the research was The students' ability in writing recount text of class XI DKV 1 Semester 1 at SMKN 1 Banyuwangi in the $2017 / 2018$ academic year. Purposive sampling was used in this research as the method to determine the area in which the research was conducted. In this action research, SMKN 1 Banyuwangi was chosen as research location. The location of this research was in SMKN 1 Banyuwangi located at Jalan Wijaya Kusuma, Giri Banyuwangi. The Respondent of this action research was detemined by using purposive sampling method. The Respondents in this research were the Class X DKV 2 SMKN 1 Banyuwangi in the 2017/2018 academic year.

Before researcher create research instrument, first draw up a table showing the relation between the variables studied with source date taken are 1). Primary Data, According to Marzuki (2002: 55) primary data is data obtained directly from the source and observed for the first time. Primary data directly relevant to the purposes of research or collected to achieve the research objectives. In this research the primary 
data is Writing recount text. 2). Secondary Data: Observation, Interview, Documentation.

The primary data from the result of the students' post test scores are going to analyze by using selecting the data obtained which is suitable with this Classroom Action Research. This data is taken from the test of composing recount through guided pictures which is focus on the aspect of unity, coherency, the use of past form. The data obtained will be analysed by using the measurement indicators of writing composition in recount through guided pictures

$$
\sum n=\frac{n}{N} \times 100 \%
$$

$\Sigma \mathrm{n}=$ the percentage of students' ability in writing composition of recount through guided pictures

$\mathrm{n}=$ The writing score of each indicator obtained by the students

$\mathrm{N}=$ The total score of the test item of each indicator.

\section{Discussion}

This classroom action research applied the strategy in order to improve the students' ability in writing composition of recount text and the strategy which was used in teaching writing composition was the use of media. Here, the researcer used guided picture as a media.

The result of preliminary test showed that the students' ability of class X DKV 1 of SMK Negeri 1 Banyuwangi in writing composition of recount was lower. It was caused by the individual factor of students' ability in writing a composition of recount. Most of students were not able to write a composition of recount. They also said that they didn't know how to start writing a composition of recount. The result of observation and interview which are conducted by the researcher showed that the students of class $X$ DKV 2 were less interested in learning writing composition of recount, because the teaching learning process which is done by the English teacher when they got the material of writing composition of recount was not attractive. The teacher explained the material classically. The teacher didn't use the media the students interested in learning writing composition. So it made the students got boring with the material that is being explained.

By appliying the strategy of using guided pictures as the media in teaching writing composition of recount in cycle 1 and cycle 2, gradually the students' ability in writing composition of recount can be improved. It could be seen in the table of students score test in cycle 1, and the score test in cycle 2, at the last the students' ability has fulfill the target of in criteria of success.

Moreover, by using the strategy of teaching writing composition of recount through guided pictures, the students are more interested in learning writing composition of recount. 
This classroom action research used the strategy of teaching writing composition of recount through guided pictures. It is in line with the statement of Rohani that has been quoted in chapter II about picture as media.

D. Conclusion

The use of guided picture as media in teaching writing composition of recount can improve the students' ability of class X DKV 2 of SMK Negeri 1 Banyuwangi. It could be seen in test result of cycle 1 and cycle 2. From pre-action test, the students writing composition of recount score is ranged from 55 to 68, and there were 24 students. It gradually improved to $37.1 \%$, it means that the score range in cycle 1 was from 55 to 68 there were 11 students. In cycle 2, there were 9 students in the score range from 55 to 68 . It means that there was $5.7 \%$ achievement. It can be concluded that the test result from pre-action, cycle 1, to cycle 2 had improved significantly based on the criteria of success which has been stated in previous chapter that is $75 \%$.

On the other hand, it can be concluded that the students' motivation and interest in learning writing composition of recount are also improved. It means that the use of guided pictures as media in teaching writing composition of recount can made the students are more motivated interested because the teaching learning process is more active and attractive and it didn't make the students boring in learning writing composition of recount. From pre-action, cycle 1 and cycle 2, there were gradually improving in joining the class of writing composition of recount.

\section{E. Acknowledgement}

F. Reference

This paragraph template after heading 1

Last name, First name. Year. Title. Publisher

G. Main Content [replace it, as your article needed]

\section{Heading 2}

This paragraph template after heading 2.

a. Heading 3

This paragraph template after heading 3.

1) Heading 4

This paragraph template after heading 4.

\section{H. Conclusion}

This paragraph template after heading 1

\section{Acknowledgement}

First of all, I would like to thank to Allah SWT, for giving me time, chance, health to finish this thesis on time. My special thanks to my greatest consultants, H. Muhammad, M.Pd. and Prof. Dr. Miftahul Arifin, M.Pd. Who have kindly guided me with care; and allowed me to profit from their advice in writing this thesis

My Thanks also due to the following people: 
1. Drs. H. Teguh Sumarno, MM, as the Rector of UNIBA Banyuwangi.

2. Abdul Munir, M.Pd, as the Dean of Language and Art of Faculty of University of Banyuwangi.

3. Wulan Wangi, M.Pd as the Head of English Education Department of PGRI Universitas of Banyuwangi.

4. All my Sisters who supported me. Thanks for everything.

5. All my Lectures and Staffs of English Educational Department at PGRI University of Banyuwangi.

6. All my friends at PGRI University of Banyuwangi, especially from the English Education Department.

7. All people who helped me finishing this thesis.

I realize that this thesis is far for being perfect without their precious comment and critics. Therefore, I will be grateful to have others from all readers.

\section{J. Reference}

Alter, JB.1991. Guided English Skill: Composition, Comprehension, Vocabulary, Use of English. Jakarta: Primary 2, Bina Karya.

Anderson, A. and Aderson, K.1997.Text Types in English 2.South Yara: MacMillan Education Australia PTY CTD.

Aqib, Zainal.2007. Penelitian Tindakan Kelas. Jakarta: Yaama Widya.

Brown, J.W. et al. 1959. Instructional Materials and Methods. New York: McGraw - Holl Book Company, Inc.

Brown,H.P. 2001. Teaching English by Principal and Interactive Approach to Language Pedagogy. New York: Longman.

Fadloli,O. 1968. Buku Materi Pokok Writing IIA Modul 1-3. Jakarta: Karonika VI.

Faye, V., et al. 1985. ESL Composition. USA. Newbary House Publisher Inc.

Hamalik, O. 1978. Media Pendidikan. Bandung: PT. Cipta Aditya Bakti.

Handayani Eko.2 et.al.2010.Improving the Ability of the Eighth Year Students of SMPN 1 Kalipuro Banyuwangi In Writing Recount Through Guided Pictures.Islamic University of Malang.

Harmer, Jeremy.1998. How to teach English. Essex: Pearson Education Limited.

Harmer, Jeremy.2007. How to teach Writing. Essex: Pearson Education Limited.

Heaton, J.B. 1984. Writing English Language Test. Singapore: Longman Group Ltd. 
Hughes, A. 1984. Testing for Language Teacher. London. Longman.

Muslich, Masnur. 2009. Melaksanakan PTK Itu Mudah. Jakarta: Bumi Aksara.

Noeng Muhajir. 2000. Metodologi Penelitian Kualitatif. Yogyakarta: Rake Sarasin. Indonesia.

Noor, A.V. 1981. Preparing and Using AIDS for English Language Teaching. Singapore: Oxford University Press.

Rohani. 2001. Media Pengajaran. Bandung: Sinar Baru

Suharsimi, Arikunto.2006.Metodologi Penelitian.Yogyakarta: Bina Aksara.

Tim Pelatih Proyek PGSM. 1999. Penelitian Tindakan Kelas. Depdikbud Dirjen Dikti. Proyek Pengembangan Guru Sekolah Menengah. Indonesia.

Wright, Andrew.1989. Pictures For Language Learning.Cambridge:Cambridge University Press.

Zumakshin and Yulia Mufarichah. 2007. Progress A contextual Approach to Learning English. Jakarta. Ganeca Exact 